\title{
Abbreviations, dates, spelling and punctuation
}

AECP (A) La Courneuve, Paris, Affaires Étrangères, Correspondence Politique (Angleterre)

AEMD (A) La Courneuve, Paris, Affaires Étrangères, Mémoires et Documents

(Angleterre)

AN Archives Nationales

BL British Library

DNB Oxford Dictionary of National Biography

HMC Historical Manuscripts Commission

NLS National Library of Scotland

NRS National Records of Scotland

RPS Www.rps.ac.uk/: Records of the Parliaments of Scotland to 1707

SHD Service Historique de la Défense (Vincennes)

Because the British Isles remained on the Julian calendar until 1751, dates there were ten calendar days behind those of Continental Europe until 1701 and eleven days behind thereafter (up to 1751). All of the correspondence and documents cited below stemming from Continental locations have therefore had the old-style, British Isles, date added in the following form: 3/14. Thus a letter written in Paris on 14 May would be cited below as having been written on 3/14 May. Officially the new year also did not begin in the British Isles until 25 March, though many contemporary British writers had silently adopted the Continental practice of beginning the year on 1 January. The first of January has been taken as the start of the new year throughout this book.

The spelling and punctuation of all quotations has been modernised wherever this helps elucidate the meaning of the text. Commonplace contractions and abbreviations have all been silently expanded. 
Daniel Szechi - 9781847799890 Downloaded from manchesterhive.com at $04 / 26 / 2023$ 12:01:56PM via free access 